\title{
PRINSIP GOOD FAITH (ITIKAD BAIK) DALAM HUKUM KONTRAK BISNIS INTERNASIONAL
}

\author{
Cindawati* $^{*}$ \\ Fakultas Hukum Universitas Palembang, Palembang \\ Jalan Dharmapala Nomor 1A Bukit Besar, Palembang, Sumatera Selatan 30139
}

\begin{abstract}
The law of international business contracts is the law of national contract with additional of foreign substances, this principle relevant for the law of international business contracts. Writer has an interest in the issue what principle good faith in the international business contract law. Principle good faith is honesty in behavior or honesty in trade transaction, which include honesty in fact and honour towards proper trade standards, and honesty in trade transaction. Relations require good faith when contract signatory, but also not yet to close the contracts.
\end{abstract}

Keywords: good faith principle, international contract.

\section{Intisari}

Hukum Kontrak Internasional adalah hukum kontrak nasional yang ada unsur asingnya, prinsip ini relevan bagi Hukum Kontrak Internasional. Penulis tertarik untuk mengkaji dengan permasalahan: apa prinsip good faith (itikad baik) dalam hukum kontrak internasional? Prinsip good faith (itikad baik) tidak lain adalah "kejujuran" dalam perilaku atau kejujuran dalam bertransaksi dagang, termasuk di dalamnya adalah kejujuran dalam fakta dan penghormatan terhadap standar-standar dagang yang wajar dan transaksi dagang yang jujur. Hubungan mensyaratkan kewajiban itikad baik bukan saja ketika kontrak ditandatangani, tetapi juga sebelum kontrak ditutup.

Kata kunci: prinsip good faith, kontrak internasional.

\section{Pokok Muatan}

A. Pendahuluan 182

B. Pembahasan 184

1. Hukum Kontrak Bisnis Internasional 184

2. Prinsip Good Faith (Itikad Baik) 191

C. Kesimpulan 193

Alamat korespondensi: cindawati_s@yahoo.com 


\section{A. Pendahuluan}

Berkenaan dengan perdagangan internasional (bisnis internasional) yang menghendaki kecepatan dan kepastian, salah satunya adalah praktek perdagangan internasional yang sangat menghendaki harmonisasi dan asas keseimbangan, adalah hukum di bidang transportasi, baik laut, darat maupun udara. Hukum yang dimanfaatkan dalam perdagangan internasional karena melibatkan banyak negara, maka melibatkan banyak hukum yang tidak seragam, sehingga seringkali banyak permasalahan, yaitu: Pertama, kekuatan hukum negosiasi, berbeda-beda antara hukum di satu negara dengan negara lain. Ada sistem hukum yang mensyaratkan bahwa negosiasi kontrak belum mengikat sama sekali sebelum kontrak ditandatangani. Sistem hukum di Indonesia (berdasarkan KUH Perdata) menganut sistem ini. Akan tetapi ada sistem di negara tertentu secara tegas menyatakan, bahwa negosiasi tidak mengikat berdasarkan ikatan yang disebut preliminary contract. Apabila terjalin perjanjian akan menimbulkan masalah yang harus diselesaikan di pengadilan. Pada umumnya di negara yang menganut Sistem Hukum Common Law. Negosiasi sudah dianggap mengikat. ${ }^{1}$ Pada umumnya pesanan-pesanan (order) pembelian ataupun penjualan ke dan dari luar negeri adalah sebagai hasil dari pembicaraan yang dilakukan sebelumnya antara pembeli dan penjual. Oleh karena pembeli dan penjual dalam jarak yang berjauhan, maka sebagai penghubung (komunikasi) biasanya telah dipergunakan pertukaran surat-menyurat ataupun dengan saling mengirim kawat. Dalam zaman modern ini, yang mana faktor waktu sudah sangat diperhitungkan, maka pemakaian kawat telex, telepon dan faksimile sudah menjadi umum dalam melakukan transaksi dengan luar negeri. Di dalam surat-menyurat antara penjual dan pembeli (eksportir dan importir) akan didapati pembicaraan pendahuluan mengenai suatu transaksi yang berisi permintaan penawaran barang, harganya, dan lain- lain syarat. Permintaan penawaran ataupun catatan harga dari calon pembeli kepada calon penjual dalam bahasa asingnya disebut dengan "an inquiry for a quatation" dan pihak penjual (eksportir) mengirimkan suatu penawaran (offer). Kedua, akseptasi yang tidak sama dengan tawaran. Akseptasi atau penerimaan tawaran oleh salah satu pihak dalam jual beli internasional tidak persis sama dengan tawaran (offer) yang telah dilakukan oleh pihak lain. Terhadap kejadian seperti ini pengaturan hukum di satu negara dengan negara lain bervariasi. Hukum Perdata Indonesia, menganggap apabila terdapat perbedaan antara offer oleh salah satu pihak dam akseptasi oleh pihak lain, maka kita sepakat dianggap tidak terbentuk, sehingga kontrak belum dianggap terjadi (Pasal $1320 \mathrm{KUH}$ Perdata: sepakat, kecakapan, suatu hal tertentu dan suatu sebab yang halal). Akan tetapi hukum di USA melihat akseptasi secara gradual, artinya dilihat seberapa jauh penyimpangan dilakukan dalam akseptasi tersebut. ${ }^{2}$ Jika penyimpangannya tidak materiil atau signifikan terhadap kontrak, dan kontrak tetap terjadi dan penyimpangan tersebut, dianggap merupakan bagian dari kontrak. Sebaliknya kalau penyimpangan tersebut bersifat materiil atau signifikan, maka kontrak tetap dianggap telah terjadi, sementara penyimpangan tadi tidak dianggap bagian dari kontrak. Ketiga, penawaran suatu tawaran. Secara umum di USA menganggap tawaran selalu dapat dibatalkan sebelum adanya kata sepakat. Akan tetapi di negara-negara yang mempunyai ketentuan hukum yang menyatakan penawaran atau offer merupakan perbuatan sepihak, apabila suatu waktu tertentu yang pantas (reasonable time) maka offer sudah tidak dapat dicabut lagi, kecuali dibatalkan oleh kedua belah pihak. Penawaran atau offer ini ada bermacam-macam antara lain: free offer, dimana penjual hanya mencantumkan catatan harga barang yang sifatnya tidak mengikat (without engagement). Di samping itu juga dikenal dengan firm offer, di 
mana penjual menentukan baik harga maupun syarat-syarat lainnya untuk suatu jangka waktu tertentu. Pihak pembeli dapat mengambil keputusan yang mengikat dalam jangka waktu itu, dalam arti untuk menerima penawaran itu beserta syarat-syarat yang disebut. Keempat, consideration dalam jual beli, adalah suatu tindakan yang dilakukan atau tidak dilakukan oleh salah satu pihak sebagai imbalan prestasi yang dilakukan oleh pihak lain berdasarkan suatu kontrak. Tanpa adanya kontrak, tidak adanya keharusan baginya untuk melakukan atau tidak melakukan suatu tindakan. Contohnya, pihak pembeli melakukan consideration berupa membayar harga barang tersebut. Di negara menganut sistem Common Law (Anglo Saxon), konsideran merupakan syarat sahnya suatu kontrak dengan beberapa pengecualian dan sudah semakin berkurang daya berlakunya. Sementara di Eropa Kontinental, termasuk Belanda dan Indonesia tidak memberlakukan doktrin consideran. Kelima, keharusan kontrak tertulis. Keenam, waktu dianggap terjadinya kata sepakat. Beberapa negara yang memberlakukan ketentuan bahwa akseptasi telah terjadi, dan karena itu kata sepakat telah tercapai. Pada saat pihak penerima tawaran tersebut secara wajar mengirim akseptasinya (persetujuannya) kepada pihak yang melakukan offer (tawaran). Apabila dibandingkan dengan BW Belanda Baru (NBW), segi praktis terjadinya kontrak sudah diatur dengan tegas dan mengikuti prinsip-prinsip UNIDROIT. Pasal 217 NBW menyatakan: (1) A contract is formed by formed by an offer and its acceptance, (2) Articles 219-225 apply unless the offer, another juridical act or usage produce a different result. ${ }^{3}$

Melalui kesepakatan yang dibuat ini, terjadinya perjumpaan kehendak terciptalah kekuatan mengikat yuridikal. Keterikatan yuridikal dalam suatu perjanjian timbul dari kesepakatan manusia satu sama lain. Tetapi negara yang menganggap akseptasi terjadi saat diterima oleh pihak yang melakukan offer. Ada negara yang menganut prinsip subyektif, akseptasi dianggap ada ketika pihak melakukan offer mengetahui secara nyata (actual knowledge). ${ }^{4}$ Dari beberapa kekhasan dalam Hukum Kontrak Bisnis atau Jual Beli Internasional ini terdapat persoalan yuridis, yang mana fenomena yang mewarnai perdagangan internasional kalau diperhatikan dengan seksama dalam perdagangan internasional yang membenturkan dua negara dengan sistem hukum yang berlaku. Dengan demikian pembeli (importir) memberitahukan kepada penjual (eksportir) akan persetujuannya. Persetujuan pembeli (importir) atas suatu penawaran itu disebut sebagai acceptance. Dengan adanya penawaran yang disetujui oleh calon pembeli, maka telah terjadi kesepakatan. Adanya perjumpaan kehendak di sini sudah ada keterikatan yuridikal. Dari sudut hukum sudah terjadi transaksi jual beli yang biasanya disebut dengan contract of sale atau agreement to sale. Keterikatan yuridikal dalam suatu perjanjian timbul dari kesepakatan manusia satu sama lain. Dampak keadaan yang tidak terduga terhadap asas kekuatan mengikat kontrak erat terkait dengan asas keseimbangan, yang pada gilirannya berkaitan dengan batas-batas dari kekuatan mengikat tersebut. Di balik "kehendak untuk terikat" dapat ditemukan elemen yang sejatinya menjadi dasar pembenar bagi kekuatan mengikat pencapaian tujuan bersama. Secara umum elemen inilah yang menjamin tercapainya hasil akhir yang adil. Pembenaran dasariah dan perjanjian tersembunyi dibalik tujuan bersama. Bila kebendaan dijual dengan harga terlalu tinggi atau rendah, jual beli tetap dianggap absah sepanjang para pihak bersepakat, yakni sebagaimana dapat dilihat dari pernyataan kehendak mereka masing-masing. Dengan kata lain, jual beli terbentuk secara seimbang. Perjanjian bertimbal balik, yakni gagasan bahwa pergeseran kekayaan dianggap dapat dibenarkan (layak atau pantas) sepanjang tidak hanya pernyataan kehendak para

Taryana Soenandar, 2004, Prinsip-Prinsip UNIDROIT Sebagai Sumber Hukum Kontrak dan Penyelesaian Sengketa Bisnis, Sinar Grafika, Jakarta, hlm. 109.

$4 \quad$ Soedjono Dirdjosisworo, Op.cit., hlm. 37. 
pihak berkesesuaian, tetapi unsur keseimbangan telah dipenuhi. ${ }^{5}$ Janji antara para pihak hanya akan dianggap mengikat sepanjang dilandasi pada asas, adanya keseimbangan hubungan antara kepentingan perseorangan dan kepentingan umum atau adanya keseimbangan antara kepentingan kedua belah pihak sebagaimana masing-masing pihak mengharapkannya. Asas keseimbangan dilandaskan pada upaya mencapai suatu keadaan seimbang yang sebagai akibat darinya harus memunculkan pengalihan kekayaan secara absah. Di dalam dunia ekonomi, kontrak merupakan instrumen terpenting untuk mewujudkan perubahan-perubahan ekonomi dalam bentuk pembagian barang dan jasa. Ratio (dasar pemikiran) kontrak $^{6}$ merujuk pada tujuan terjadinya pergeseran harta kekayaan secara adil (gerechtvaardigde) dan memunculkan akibat hukum terjadinya pengayaan para pihak juga secara adil. Untuk itu juga konsep keadilan memasuki memasuki ranah hukum perdagangan internasional dan menempatkan "justice as right order". 7 Kontrak mengejawantahkan ke dalam maksud dan tujuan menciptakan keadaan yang lebih baik (een beter leven brengen) bagi kedua belah pihak. Agar pertukaran sebagai pengayaan yang adil, dapat dipandang sebagai fair exchange, maka suatu prestasi harus diimbangi dengan kontraprestasi. Pertukaran secara bertimbal balik merupakan konsep kunci bagi terciptanya keadilan di atas. Kontrak memiliki tiga tujuan dasar, sebagai berikut: Tujuan pertama, dari suatu kontrak ialah memaksakan suatu janji dan melindungi harapan wajar yang muncul darinya. Esensi kontrak adalah janji atau sekumpulan janji yang dapat dipaksakan pelaksanaannya, atau dapat pula dikatakan sebagai persetujuan yang dipaksakan berlakunya menurut hukum. Tujuan kedua, dari suatu kontrak ialah mencegah pengayaan (upaya memperkaya diri) yang dilakukan secara tidak adil atau tidak benar.
Tujuan ketiga, ialah tentu mencegah bermacammacam kerugian (to prevent certain kinds of harm). Untuk itu penulis tertarik dengan permasalahan: apakah prinsip good faith (itikad baik) dalam kontrak bisnis internasional?

\section{B. Pembahasan}

\section{Hukum Kontrak Bisnis Internasional}

Pengertian Hukum Kontrak Bisnis Internasional adalah sekumpulan ketentuan yang mengatur pembentukan (formation), aktivitas di bidang ekonomi/industri (performance), dan pelaksanaan (implementation) kontrak antara para pihak, baik yang bersifat nasional maupun internasional. Tujuan utamanya adalah melindungi harapan individu (yang sesuai dan dapat dibenarkan oleh hukum), bisnis dan pemerintah. ${ }^{8}$

Asas keseimbangan dalam hukum kontrak jual beli Internasional di dalam kontrak bisnis merupakan instrumen terpenting untuk mewujudkan perubahanperubahan dalam bentuk pembagian barang dan jasa. Ratio (dasar pemikiran) kontrak merujuk pada tujuan terjadinya pergeseran harta kekayaan secara adil (gerechtvaardigde) dan memunculkan akibat hukum terjadinya pengayaan para pihak secara adil (perjanjian pada prinsipnya mengakibatkan pengayaan secara legal). Bila pembeli tidak dapat menyetujui seluruh syarat-syarat dalam penawaran itu (firm offer), maka pembeli dapat mengajukan usul-usul perubahan yang diingini. Permintaan perubahan dari calon pembeli atas suatu penawaran disebut counter offer. Dalam hal calon penjual dapat menyetujui usul-usul perubahan itu berarti calon penjual bersedia memperbaharui penawaran. Berdasarkan penawaran yang baru itulah disusun transaksi jual beli (sales contract) di mana kedua pihak mengikatkan diri melakukan perjanjian jual beli dengan syarat-syarat yang telah dimufakati. Sales contract ini disebut order note, purchase

Herlien Budiono, 2006, Asas Keseimbangan Bagi Hukum Perjanjian Berlandaskan Asas-Asas Wigati Indonesia, Citra Aditya Bakti, Bandung, hlm. 471.

Ibid., hlm. 308.

Ade Maman Suherman, "Perdagangan Bebas (Free Trade) dalam Perspektif Keadilan Internasional", Indonesian Journal of International Law, Vol. 5, No. 2, Januari 2008, hlm. 256.

Syahmin A. K., 2004, Hukum Kontrak Internasional, Raja Grafindo Persada, Jakarta, hlm. 20. 
note atau juga disebut import contract note. Yang isinya menyebutkan referensi dari korespondensi terdahulu, pernyataan penetapan/penempatan pesanan, uraian barang, penentuan harga satuan dan jumlah harga, waktu pengiriman barang, cara pengepakan, merk/cap pengepakan yang diingini, dokumen pengapalan (shipping document) yang diperlukan, syarat pembayaran, asuransi dan sebagainya yang dianggap perlu. Dengan demikian apapun yang berpengaruh terhadap pembentukan kehendak, hal itu bukanlah semata-mata motif para pihak yang dapat diungkap serta dikenali, namun mencakup juga motif yang sepatutnya diketahui pihak lawan sekalipun motif tersebut tidak tampak. Semakin tingginya pengharapan, semakin bermuara pada perluasan secara prinsipil dari ruang lingkup maupun kualitas kewajiban pihak yang mengikatkan diri pada perjanjian tersebut. Perincian ketentuan muatan dan isi atau cakupan perjanjian terjadi dengan cara merujuk pada kewajiban pemberitahuan, penelitian, dan penyampaian informasi, yakni dengan tujuan agar kehendak yang terbentuk menjadi selaras dengan maksud dan tujuan para pihak.

Dalam menyusun kontrak penjualan (sales contract) relevan untuk diperhatikan hal-hal sebagai berikut: ${ }^{9}$

a. Uraian barang-barang (description of goods), harus dibuat sejelas-jelasnya oleh kedua belah pihak baik pembeli maupun penjual. Bilamana barang tersebut sudah mempunyai mutu baku internasional (international standard quality), maka dalam menentukan mutu disebutkan mutu baku ini, misalnya karet alam, gula, kapas dan sebagainya. Mengenai industri, di samping keterangan tehnik (technical spesification), harus disebutkan nama pabriknya, seperti Singer, Philips, Siemens, dengan melampirkan brochure atau leaflet.

b. Jumlah barang (quantity), penetapan istilah mengenai kuantum (jumlah barang) harus jelas sehingga tidak mungkin timbul perselisihan tafsiran. Sebagaimana diketahui terdapat bermacam-macam satuan hitung, sehingga dalam hal ini perlu disebutkan dengan lengkap dan sempurna satuan hitung yang dimaksudkan, contoh 10 ton gula.

c. Harga (price), dalam menentukan harga jual beli, di samping jenis mata uang, harus jelas syarat-syarat penyerahannya harus tegas. Mengenai jenis mata uang harus ditegaskan, misalnya English Pound Sterling, Australian Dollar (A.\$), United States Dollar (US\$), Singapore Dollar (S\$), Hongkong Dollar (H\$), Uni Eropa (Euro).

d. Tempat penyerahan barang (place of delivery), syarat penyerahan barang harus ditentukan secara tepat karena kaitannya untuk menentukan harga dari suatu transaksi, di samping syarat penyerahan barang harus dijelaskan, nama tempat, penyerahan itu akan dilakukan secara phisik. Ini penting untuk mengetahui batas tanggung jawab masing-masing pihak penjual maupun pembeli.

Tujuan pokok memilih "syarat perdagangan" dalam perdagangan internasional adalah untuk menentukan pada titik atau tempat mana penjual harus memenuhi kewajibannya melakukan "penyerahan" barang secara yuridis kepada pembeli "titik" atau "tempat" penyerahan itu, juga merupakan titik batas di mana resiko atas barang (terhadap kehilangan, kerusakan pengangkutan lanjutan dan biaya penimbunan) dari penjual berakhir, dan dari "titik" atau "tempat" itu pula pembeli mulai memikul resiko atas barang itu. Jadi incoterms mengatur hak dan kewajiban serta biaya dan resiko masing-masing pihak penjual dan pembeli pada setiap syarat perdagangan. ${ }^{10}$

Dalam ketentuan Incoterms 2000 terdapat empat (4) golongan mode transport, yakni: ${ }^{11}$

\footnotetext{
Amir M.S., 2000, Seluk Beluk dan Teknik Perdagangan Luar Negeri, PPM, Jakarta, hlm. 11.

Amir M.S., 2002, Kontrak Dagang Ekspor, PPM, Jakarta, hlm. 17.

International Commercial Terms (Incoterms), 2000.
} 
1. Syarat penyerahan barang yang berlaku untuk semua jenis pengangkutan termasuk multimodal, yang meliputi syaratsyarat:

a. EXW: Ex Works (disebutkan tempatnya/named place).

b. FCA: Free Carrier (disebutkan tempat tujuannya/named place).

c. CIP: Carriage and insurance paid to (disebutkan tempat tujuannya/named place of distination).

d. DAF: Delivered at frontier (disebutkan tempatnya/named place).

e. DDU: Delivered duty unpaid (disebutkan tempat tujuannya/ named place of distination).

f. DDP: Delivered duty paid (disebutkan tempat tujuannya/ named place of distination).

2. Pengangkutan dengan udara (air transports). Syarat yang digunakan: FCA: Free Carrier (disebutkan tempat tujuannya/named place).

3. Pengangkutan dengan kereta api. Syarat yang digunakan:

FCA: Free Carrier (disebutkan tempat tujuannya/named place).

4. Pengangkutan laut dan perairan darat (inland water way). Syarat penyerahan barang yang digunakan:

a. FAS: Free alongside ship (disebutkan pelabuhan pengirimannya/named port of shipment).

b. FOB: Free on board (disebutkan pelabuhan pengiriman/ named port of shipment).

c. CFR: Cost and freight (disebutkan pelabuhan pengiriman/named port of distination).

d. CIF: Cost, insurance and freight (disebutkan tujuan pelabuhan/ named port of distination).

e. DES: Delivered ex ship (disebutkan tujuan pelabuhan/ named and distination). f. DEQ: Delivered ex quay (disebutkan tujuan pelabuhan/ named and destination).

Syarat perdagangan dalam perdagangan internasional adalah untuk menentukan titik atau tempat di mana penjual harus memenuhi kewajibannya melakukan penyerahan barang secara fisik dan yuridis kepada pembeli. Titik atau tempat penyerahan itu juga merupakan titik batas di mana risiko atas barang (terhadap kehilangan, rusak, urusan angkutan lanjutan, dan biaya penimbunan) dari penjual berakhir, dan dari titik atau tempat itu pula pembeli mulai memikul risiko atas barang. Syarat perdagangan menurut Incoterms 2000, ICC Publication 560 mulai berlaku sejak 1 Januari 2000, Jakarta. Incoterms (The International Commercial Terms), dibentuk untuk memberikan definisi baku secara universal mengenai istilah-istilah yang digunakan dalam transaksi perdagangan internasional seperti FOB, CIF. Praktek perdagangan internasional yang secara standar dan praktis menjadi pedoman dalam form sederhana memotong batasan-batasan hukum kontrak yang tradisional dan rumit. KADIN (Kamar Dagang dan Industri Internasional) atau Incoterms 2000 (International Chamber of Commerce) sebagai pegangan untuk "sales contract" ke luar negeri dan kontrakkontrak lanjutannya seperti yang berkaitan dengan perbankan, perusahaan angkutan (EMKL), asuransi, bea cukai, pajak. ${ }^{12}$ Aspek dan elemen penting dalam kontrak standar khususnya sales contract. Jika para pengusaha mengadakan perjanjian antara sesama pengusaha umumnya sudah dapat dipahami, bahwa dengan syarat-syarat yang mereka setujui bersama, mereka akan mencapai tujuan ekonomi yang mereka harapkan. Hal ini tidak menimbulkan masalah karena kedua pihak telah memahami makna syaratsyarat yang ditentukan itu.

Syarat-syarattersebut dirumuskan sedemikian rapi, sehingga menjadi syarat-syarat yang berlaku untuk semua orang yang membuat perjanjian ekonomi dengan pengusaha yang 
bersangkutan. Dengan kata lain syarat-syarat itu dibakukan, artinya ditetapkan sebagai tolok ukur bagi setiap pihak yang membuat perjanjian ekonomi dengan pengusaha yang bersangkutan. ${ }^{13}$ Perjanjian berstandar disebut juga perjanjian standar, dalam bahasa Inggris disebut Standard Contract, Standard Agreement. Kata "baku" atau "standar", artinya tolok ukur yang dipakai sebagai patokan. Dalam hubungan ini, perjanjian baku artinya perjanjian yang menjadi tolok kukur yang dipakai sebagai patokan atau pedoman bagi setiap konsumen yang mengadakan hubungan hukum dengan pengusaha. Yang dibakukan dalam perjanjian baku, ialah meliputi model, rumusan, dan ukuran. ${ }^{14}$

Sesuai dengan perkembangan kebutuhan masyarakat, maka ciri-ciri perjanjian baku mengikuti dan menyesuaikan dengan perkembangan tuntutan masyarakat. Ciri-ciri tersebut mencerminkan prinsip ekonomi dan kepastian hukum yang berlaku di negara-negara yang bersangkutan. Prinsip ekonomi dan kepastian hukum dalam perjanjian baku dilihat dari kepentingan pengusaha bukan dari kepentingan konsumen. Dengan pembakuan syarat-syarat perjanjian, kepentingan ekonomi pengusaha lebih terjamin karena konsumen hanya menyetujui syarat-syarat yang disodorkan oleh pengusaha. ${ }^{15}$ Menurut Pitlo, perjanjian baku sebagai perjanjian paksa (dwang contract), walaupun secara tertulis yuridis, perjanjian baku ini tidak memenuhi ketentuan Undang-Undang dan oleh beberapa ahli hukum ditolak namun kenyataannya, kebutuhan masyarakat berjalan dalam arah yang berlawanan dengan keinginan hukum. Menurut Stein, mencoba memecahkan masalah ini dengan mengemukakan pendapat bahwa perjanjian baku dapat diterima sebagai perjanjian, berdasarkan fiksi adanya kemauan dan kepercayaan (fictie van wil en vertrouwen) yang membangkitkan kepercayaan bahwa para pihak mengikatkan diri pada perjanjian itu. Jika debitur menerima dokumen perjanjian itu, berarti ia secara sukarela setuju pada isi perjanjian tersebut. ${ }^{16}$ Hondius di dalam disertasinya mempertahankan bahwa perjanjian baku mempunyai kekuatan mengikat, berdasarkan kebiasaan (gebruik) yang berlaku di lingkungan masyarakat dan lalu lintas perdagangan. ${ }^{17}$ Hukum kontrak internasional dalam bentuk kontrak baku, negara-negara sudah merasakan pentingnya peran perdagangan dalam meningkatkan pertumbuhan perekonomiannya. Kesempatan ini disambut oleh pedagang, mereka cukup banyak membentuk berbagai asosiasi dagang sesuai dengan bidang usaha dagangnya. Keberadaan asosiasi dagang ini antara lain bertujuan memfasilitasi dan memperlancar usaha dagang mereka. Salah satu cara atau upaya memfasilitasi ini antara lain adalah memperkenalkan bentuk-bentuk kontrak baku atau standar. Satu hal lain yang perlu diperhatikan dalam kaitannya dengan kontrak baku adalah penuangannya. Kontrak baku atau kontrak standar dapat dicantumkan melalui penguraian dalam dokumen kontrak atau hanya melalui penunjukan saja. Contoh yang terakhir yaitu incorporation of terms by reference, misalnya syarat-syarat perdagangan yaitu FOB, CIF. Tanggung jawab hukum dengan syarat perdagangan FOB, CIF dengan contoh Kasus Ekspor Impor Pupuk PT Pusri dengan syarat perdagangan FOB dan CIF:

\section{FOB Price (Free on Board)}

Dalam contoh kasus, PT Pusri sebagai eksportir pupuk urea dalam perdagangan luar negeri dengan tujuan ekspor ke negara Filipina, Australia, Cina, Vietnam dan Korea, dengan syarat perdagangan FOB. Tujuan pokok PT Pusri memilih syarat

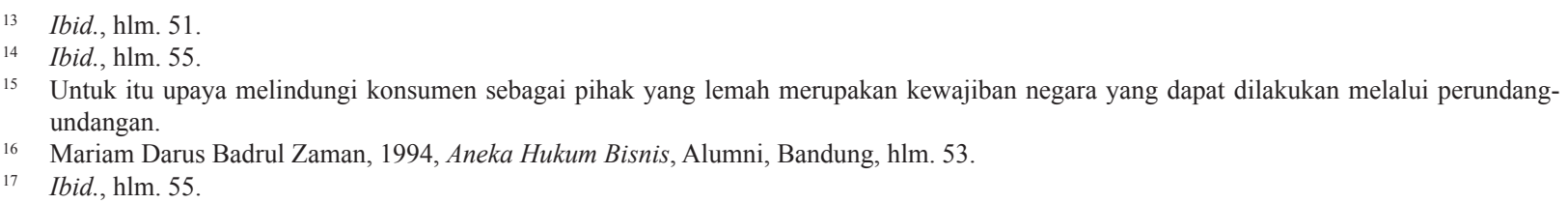


perdagangan ini untuk menentukan titik atau tempat dimana penjual harus memenuhi kewajibannya melakukan penyerahan barang secara fisik dan yuridis kepada pembeli. Titik atau tempat penyerahan itu juga merupakan titik batas dimana risiko atas barang (terhadap kehilangan, kerusakan, urusan angkutan lanjutan dan biaya penimbunan) dari penjual berakhir, dan titik itu pula pembeli mulai menanggung risiko atas barang. Tanggung jawab hukum PT Pusri (sebagai kewajiban) adalah mengurus izin ekspor dan menyerahkan barang sampai di atas kapal pelabuhan muat (loading port) dari titik atau tempat penyerahan inilah secara fisik dan yuridis sudah beralih dari PT Pusri kepada pembeli. Faktor-faktor yang mempengaruhi PT Pusri memilih syarat perdagangan FOB (Free on Board) ini karena: (a) susah mencari kapal atau jumlah kapal dikurangi, (b) PT Pusri tidak mau mengambil risiko kerusakan, kehilangan barang, walaupun sebagai penjual (eksportir) PT Pusri menjual harga pupuk Urea lebih murah, pembeli mempunyai kewajiban yang menanggung semua biaya dan risiko kerusakan dan kehilangan mulai dari batas ini. Harga FOB mencakup harga barang, biaya pengangkutan ke dermaga, serta biaya pengangkutan ke atas kapal.

\section{CIF (Cost, Insurance and Freight)}

Contoh kasus, PT Pusri sebagai importir (pembeli) KCL (kalium klorida) yang diimpor (dibeli) dari Rusia, Canada, dan Jerman, dengan syarat perdagangan CIF (cost, insurance and freight). Kewajiban eksportir (penjual) ${ }^{18}$ adalah mengurus izin ekspor, dan menyerahkan barang sampai di atas kapal di pelabuhan tujuan tempat pembongkaran (discharging port) dan menanggung biaya-biaya dan ongkos angkut kapal sampai ke pelabuhan tujuan (destination port). Setelah penyerahan barang di pelabuhan bongkar sampai kapal sandar, kapal menyediakan derek, cran untuk bongkar barang. Tanggung jawab hukum eksportir yang menyerahkan barang sampai pelabuhan bongkar, sedangkan tanggung jawab hukum PT Pusri sebagai importir adalah sejak menerima barang secara fisik dan yuridis, tempat pelabuhan bongkar (discharging port) dan melaksanakan pembongkaran. Jika terjadi kerusakan setelah selesai pelaksanaan pembongkaran di pelabuhan bongkar (discharging port) adalah pihak importir. PT Pusri berkewajiban melaksanakan pembayaran senilai invoice melalui Bank Pembuka (opening bank), jika dokumen pengapalan (shipping document) lengkap dan sesuai dengan persyaratan dalam L/C. PT Pusriberhak menerima barang yang dipesan di pelabuhan bongkar, dan melaksanakan pembongkaran sesuai dengan kesepakatan syarat perdagangan CIF (Cost Insurance and Freight), disebut nama pelabuhan tujuan. Harga CIF $^{19}$ sudah mencakup harga barang, biaya sampai ke pelabuhan tujuan, biaya pengangkatan dan biaya tambang hingga barang dikapalkan, serta biaya asuransi. Kalau penawaran dengan 
menyebutkan syarat penyerahan pada suatu pelabuhan tertentu, maka perlu sekali penelitian apakah pelabuhan yang disebut itu pelabuhan ekspor (Point/Port of Exportation) ataukah hanya Inland Port. Bilamana pelabuhan yang disebut hanyalah Inland Port, maka ada kemungkinan barang itu harus diangkut lagi melalui jalan darat atau lainnya sampai ke pelabuhan ekspor. Menghadapi hal semacam ini perlu diperhitungkan kemungkinan ekstra ongkos angkut.

\section{Pembiayaan Ekspor dan Impor}

Dalam transaksi perdagangan internasional yang dilakukan oleh penjual (eksportir) dan pembeli (importir) akan timbul hak-hak dan kewajiban bagi masing-masing pihak. Eksportir wajib melakukan penyerahan barang dan berhak untuk menerima pembayaran atas penyerahan barang. Di sisi lain importir wajib melunasi harga barang dan berhak untuk menuntut penyerahan barang yang dibelinya. Sedangkan lahirnya "hukum" akan merupakan ekspresi atau pencerminan aspirasi dari pihak-pihak (pelaku bisnis) untuk perlindungan hak-hak dan kepentingan kedua belah pihak, dengan norma-norma yang bermuatan sanksi bagi pihak yang melakukan wanprestasi. Ketentuan mengikat ini secara tegas telah mengatur sejak kontrak disepakati (ditandatangani) kedua belah pihak, seperti sejak mulai persiapan pengiriman barang yang membutuhkan dana untuk kegiatan persiapan sampai dengan pengapalan, resiko dalam perjalanan, sehingga kesemuanya terlaksana dengan pembayaran pihak pembeli (importir). Kesemuanya mencerminkan "rule of the game" yang jelas dan rinci. Oleh karena itu, dalam setiap kontrak bisnis harus diawali dengan kecermatan masing-masing pihak untuk mempelajari klausula kontrak, yang pada umumnya berdasarkan kontrak atau perjanjian baku (berstandar). Kecermatan dan kehati-hatian masingmasing pihak adalah faktor antisipatif yang bijaksana. Dalam mewujudkan Hukum Perdagangan Internasional yang "adil" dibutuhkan suatu prinsip atau asas yang menjamin hak dan kepentingan kedua belah pihak. Asas yang dimaksud adalah "asas keseimbangan", yang relatif dapat dimengerti oleh pandangan umum yang mendambakan kedamaian dan keadilan. Transaksi ekspor-impor menghadapkan para pelaku bisnis antar negara, dalam pelaksanaannya, memerlukan berbagai persyaratan yang komprehensif dan menarik perhatian institusi atau kelembagaan internasional yang peduli akan kemajuan perdagangan internasional, kerja sama ekonomi dunia baik regional maupun internasional. Dalam melaksanakan transaksi perdagangan internasional itu, kebanyakan eksportir dan importir membutuhkan pembiayaan disebut pembiayaan ekspor (export financing), dibutuhkan untuk menutup kebutuhan dana modal kerja mereka sebelum atau sesudah pengapalan barang. Sebelum pengapalan barang eksportir membutuhkan dana untuk membiayai produksi atau pengumpulan barang yang dipesan importir. Yang dimaksud dengan pembiayaan jangka pendek adalah pembiayaan untuk jangka waktu kurang dari satu tahun. Mereka juga membutuhkan dana untuk membiayai persediaan barang yang 
disimpan dalam gudang sebelum pesanan diterima dari luar negeri atau barang yang diberangkatkan.

a. Pembiayaan Jangka Pendek Berjaminan Komoditas

Dokumen pengapalan atau Konosemen (bill of lading) berfungsi sebagai tanda kepemilikan barang yang dikapalkan. Oleh karena itu apabila eksportir terdesak kebutuhan dana dan tidak dapat menunggu saat pembayaran dari pembeli luar negeri.

b. Pembiayaan Perdagangan Internasional dengan Jaminan Surat Tanda Kepemilikan Barang dalam Gudang (Ware House Receipts) atau FAWR (Financing Against Warehouse Receipts)

Contoh kasus, dengan jaminan SuratTanda Kepemilikan Barang dalam Gudang (Ware House Receipts), lazim dipergunakan dalam perdagangan komoditas perkebunan dan pertanian, seperti biji coklat, kopi, karet, gula, kapas, kedelai, gandum, beras serta komoditas hasil tambang seperti alumunium ingots, zink ingots, copper. Komoditas tersebut di atas diperdagangkan di Bursa Komoditas Internasional London Metals Exchange (LME) di London, Inggris. FAWR dapat membantu eksportir dan importir membiayai kebutuhan dana modal kerja yang mereka perlukan dalam menjalankan kegiatan bisnisnya, sambil menunggu datangnya kapal yang akan mengangkut barang (warehouse). Mungkin juga eksportir harus memproduksi terlebih dahulu atau mengumpulkan barang yang akan diekspor sedikit demi sedikit dari pemasok di berbagai daerah, kemudian disimpannya di gudang sambil menunggu datangnya pesanan dari luar negeri. Pengumpulan komoditas seperti beras, gula, kopi, coklat, getah karet atau tembakau sedikit demi sedikit sebelum diekspor, banyak dilakukan para pedagang eksportir komoditas perkebunan dan pertanian. Selain itu ada perusahaanperusahaan eksportir besar untuk menguasai pasar menyimpan persediaan barang di pusat perdagangan luar negeri, sehingga dengan cepat dapat melayani setiap pesanan barang yang datang dari pelanggan luar negeri mereka. Barangbarang yang disimpan dalam gudang dapat dipergunakan untuk jaminan pada saat eksportir membutuhkan bantuan pembiayaan jangka pendek dari pihak ketiga.

\section{Prinsip Good Faith (Itikad Baik)}

Prinsip ini mengandung makna berbedabeda di antara sistem hukum. Pengertian dan pemahaman itikad baik tampak berbeda khususnya di antara Sistem Hukum Kontinental dan Common Law. Menurut Subekti, essensi (prinsip) ini merupakan salah satu sendi yang terpenting dalam Hukum Perjanjian. ${ }^{20}$ Menurut Sudargo 
Gautama, ${ }^{21}$ Hukum Kontrak Internasional tidak lain adalah hukum kontrak nasional yang ada unsur asingnya, maka prinsip ini relevan bagi Hukum Kontrak Internasional. Itikad baik tampak berbeda khususnya di antara Sistem Hukum Kontinental dan Common Law:

\section{a) Prinsip Itikad Baik dalam Sistem Hukum Kontinental}

Dalam Sistem Hukum Kontinental, pendekatan terhadap prinsip ini didasarkan pada filosofi dari kontrak yang menitikberatkan atau memusatkan pada hubungan para pihak. ${ }^{22}$ Hubungan ini mensyaratkan kewajiban itikad baik bukan saja ketika kontrak ditandatangani, tetapi juga sebelum kontrak ditutup. Misalnya, Kitab Undang-Undang Hukum Perdata Belgia, negara ini mensyaratkan semua kontrak dilaksanakan dengan itikad baik dan penafsiran (kontraktualnya) pun harus disertai dengan kebiasaan. ${ }^{23}$

\section{b) Prinsip Itikad Baik dalam Sistem Common Law}

Khususnya Inggris, tidak mengenal proses negosiasi, para pihak terikat oleh prinsip beritikad baik. Menurut Hukum Inggris, masuknya para pihak ke dalam negosiasi tidak dengan serta merta melahirkan kewajiban itikad baik. Menurut Hukum Inggris, selama kontrak belum ditandatangani, para pihak tidak terikat satu sama lain dan tidak memiliki kewajiban apapun terhadap pihak lainnya hingga kontrak tersebut akhirnya ditandatangani. ${ }^{24}$

Seperti hukum di Amerika Serikat (AS) juga berpendapat sama, bahwa itikad baik hanya ada setelah kontrak ditandatangani. Dalam Sistem Common Law, arti itikad baik tidak lain adalah "kejujuran" dalam perilaku atau kejujuran dalam bertransaksi dagang, termasuk didalamnya adalah kejujuran dalam fakta dan penghormatan terhadap standarstandar dagang yang wajar dan transaksi dagang yang jujur.

\section{c) Prinsip Itikad Baik dalam Perjanjian} Internasional

Pengakuan dan kewajiban untuk melaksanakan prinsip itikad baik diakui dalam prinsip-prinsip kontrak komersial di negara-negara yang ingin menerapkannya. Menurut UNIDROIT (The International Institute for the Unification of Private Law). Pasal 1.7 prinsip UNIDROIT menyatakan, "Each party must act in accordance with Good Faith and fair dealing in international trade" dan "The parties may not exclude or limit their duty".

Norma-norma yang telah dinyatakan secara abstrak di dalam ketentuan pasalnya, kemudian dinyatakan kembali dalam bentuk uraian penjelasan, disertai dengan contoh-contoh, oleh karena itu disebut restatement. Menurut restatement dari pasal di atas ada 3 (tiga) unsur prinsip itikad baik dan transaksi yang jujur, yaitu: Pertama, itikad baik dan transaksi jujur sebagai prinsip dasar yang melandasi kontrak; Kedua, prinsip itikad baik dan transaksi jujur dalam UPICCS (UNIDROIT Principles of International Commercial Contracts) ditekankan pada praktek perdagangan internasional; Ketiga, prinsip itikad baik dan transaksi jujur bersifat memaksa. Tujuannya adalah untuk mendorong diterapkannya prinsip itikad baik (good faith) dan kewajaran (fair dealing) dalam setiap transaksi komersial yang bersifat internasional. Manifestasi upaya mendorong harmonisasi hukum tampak ketika di dalam kontrak atau hukum nasional tidak ditemukan aturan yang diperlukan atau telah terjadi kekosongan hukum (gaps), maka prinsipprinsip UNIDROIT (The International Institute for the Unification of Private Law) dapat digunakan 
sebagai rujukan. The United Nations on Contracts for the International Sale of Goods (CISG) ${ }^{25}$ berlaku terhadap kontrak jual beli barang yang para pihaknya memilih tempat usaha di negara yang berbeda. Ruang lingkup jual beli barang dibatasi hanya untuk tujuan komersial, bukan tujuan pribadi atau kepentingan pemerintah. Sedangkan prinsip-prinsip UNIDROIT merupakan prinsip umum bagi kontrak komersial internasional yang dapat diterapkan ke dalam aturan hukum nasional, atau dipakai oleh pembuat kontrak untuk mengatur transaksi komersial sebagai pilihan hukum. Sementara transaksi bisnis serta persoalan ekonomi saat ini semakin bersifat transnasional, dipercepat dengan teknologi, sehingga muncul permasalahan baru. Prinsip-prinsip UNIDROIT adalah prinsip hukum yang mengatur hak dan kewajiban para pihak pada saat mereka menerapkan prinsip kebebasan, jika tidak diatur bisa membahayakan pihak yang lemah. Demikian pula, walaupun disadari bahwa prinsip kebebasan berkontrak bersifat fleksibel, prinsip itu bisa digunakan untuk menekan pihak yang lemah. Untuk menerapkan prinsip keseimbangan. Pengadilan atau Lembaga Arbitrase harus mampu secara kritis melihat kebebasan berkontrak dengan prinsip-prinsip UNIDROIT. ${ }^{26}$ Prinsip-prinsip UNIDROIT memberikan solusi terhadap masalah yang timbul ketika terbukti bahwa tidak mungkin untuk menggunakan sumber hukum yang relevan dengan hukum yang berlaku di suatu negara. Oleh karena itu prinsip-prinsip UNIDROIT digunakan sebagai sumber hukum yang dijadikan acuan dalam menafsirkan ketentuan kontrak yang tidak jelas. Apabila tidak ditemukan aturannya dalam hukum yang berlaku (governing law) maka prinsipprinsip tambahan, karena prinsip-prinsipnya diambil dari kebiasaan dan praktik yang seragam secara internasional. Sebagian besar prinsipprinsip UNIDROIT dimaksudkan seperangkat aturan penyeimbang untuk digunakan di seluruh dunia tanpa memperhatikan tradisi hukum dan kondisi ekonomi politik. Dari segi formal, prinsip ini menghindari penggunaan terminologi yang digunakan dalam sistem hukum tertentu. Selain itu prinsip ini merujuk pada CISG sehingga dilihat dari segi substansinya prinsip-prinsip UNIDROIT bersifat fleksibel. ${ }^{27}$ Kewajiban yang sama terdapat pula dalam The United Nations on Contract for the International Sale of Goods (CISG). Pasal 7 (1) CISG menyatakan sebagai berikut: (1) In the interpretation of Convention, regard is to be had to its international character and to the need to promote uniformity in its aplication and observance of good faith in international trade. Dalam menafsirkan konvensi ini, perhatian harus ditujukan pada sifat internasionalnya dan kebutuhan untuk mendorong keseragaman dalam pemakaiannya dan pengamatan terhadap itikad baik dalam perdagangan internasional. Prinsip ini harus dianggap ada, pada waktu negosiasi, pelaksanaan kontrak hingga penyelesaian sengketa. Prinsip ini penting karena dengan hanya adanya prinsip inilah rasa percaya yang sangat dibutuhkan dalam bisnis agar pembuatan kontrak dapat direalisasikan. Tanpa adanya good faith dari para pihak sangatlah sulit kontrak dapat dibuat. Kalaupun kontrak sudah ditandatangani, pelaksanaan kontrak tersebut pastilah akan sulit untuk berjalan dengan baik apabila prinsip ini tidak ada.

\section{Kesimpulan}

Dengan demikian ada 3 (tiga) unsur prinsip itikad baik dan transaksi yang jujur, yaitu: Pertama, itikad baik dan transaksi jujur sebagai prinsip dasar yang melandasi kontrak; Kedua, prinsip itikad baik dan transaksi jujur dalam UPICCS (UNIDROIT Principles of International Commercial Contracts) ditekankan pada praktik perdagangan internasional; Ketiga, prinsip itikad baik dan transaksi jujur bersifat memaksa. Tujuannya untuk mendorong diterapkannya prinsip itikad baik (good faith) dan kewajaran (fair dealing) dalam setiap transaksi

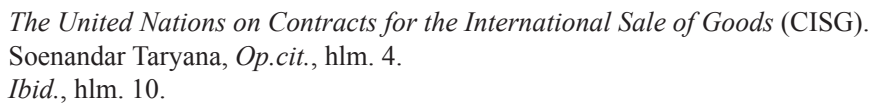


komersial yang bersifat internasional. Manifestasi upaya mendorong harmonisasi hukum tampak ketika di dalam kontrak atau hukum nasional tidak ditemukan aturan yang diperlukan atau telah terjadi kekosongan hukum (gaps), maka prinsipprinsip UNIDROIT (The International Institute for the Unification of Private Law) dapat digunakan sebagai rujukan.

\section{DAFTAR PUSTAKA}

\section{A. Buku}

Budiono, Herlien, 2006, Asas Keseimbangan bagi Hukum Perjanjian Berlandaskan AsasAsas Wigati Indonesia, Citra Aditya Bakti, Bandung.

Dirdjosisworo, Soedjono, 2006, Pengantar Hukum Dagang Internasional, Refika Aditama, Bandung.

Gautama, Sudargo, 1997, Kontrak Dagang Internasional, Alumni, Bandung.

K., Syahmin A., 2004, Hukum Kontrak Internasional, Raja Grafindo Persada, Jakarta.

S., Amir M., 2000, Seluk Beluk dan Teknik Perdagangan Luar Negeri, PPM, Jakarta. , 2002, Kontrak Dagang Ekspor, PPM, Jakarta.

Soenandar, Taryana, 2004, Prinsip-Prinsip UNIDROIT Sebagai Sumber Hukum Kontrak dan Penyelesaian Sengketa Bisnis, Sinar Grafika, Jakarta.

Subekti, 1979, Hukum Perjanjian, Intermasa, Jakarta.
Suryana, Agus, 2004, Kiat Sukses Ekspor Impor, Progress, Jakarta.

Zaman, Mariam Darus Badrul, 1994, Aneka Hukum Bisnis, Alumni, Bandung.

\section{B. Artikel Jurnal}

Suherman, Ade Maman, "Perdagangan Bebas (Free Trade) dalam Perspektif Keadilan Internasional", Indonesian Journal of International Law, Vol. 5, No. 2, Januari 2008 .

Xavier, Grace, "Global Harmonization of Contract Laws Fact, or Fiction?", Construction Law Journal, Vol. 20, No. 1, 2004.

\section{Konvensi Internsional}

The United Nations on Contracts for the International Sale of Goods (CISG).

\section{Lain-Lain}

International Commercial Terms (Incoterms), 2000. 